\title{
Role for P2X Receptors in Long-Term Potentiation
}

\author{
Yuri V. Pankratov, Ulyana V. Lalo, and Oleg A. Krishtal \\ Department of Cellular Membranology, Bogomoletz Institute of Physiology, 01024 Kiev, Ukraine
}

\begin{abstract}
ATP receptors participate in synaptic transmission and intracellular calcium signaling in the hippocampus by providing a component of the excitatory input to CA1 pyramidal neurons. The activation of P2X purinoreceptors generates calcium influx that does not require cell depolarization, but this response desensitizes at increased rates of stimulation. Here we show that inhibition of P2X receptors dramatically facilitates the induction of long-term potentiation (LTP). High-frequency stimulation (HFS) (1 sec) induced LTP in CA1, whereas brief HFS (0.2 sec) caused only short-term potentiation. However, when P2X receptors were inhibited by PPADS (pyridoxal phosphate-6azophenyl-2'-4'-disulphonic acid) or desensitized by the nonhydrolyzable ATP analog $\alpha, \beta$-methyleneATP, brief HFS reliably
\end{abstract}

induced LTP. Inhibition of P2X receptors had no facilitatory effect on LTP when NMDA receptors were blocked. We hypothesized that $\mathrm{P} 2 \mathrm{X}$ receptors affect the threshold for LTP by altering $\mathrm{Ca}^{2+}$-dependent inactivation of NMDA receptors. In isolated pyramidal CA1 neurons and hippocampal slices, activation of P2X receptors did cause inhibition of NMDA receptor-mediated current. We suggest that, by controlling the background calcium and thus the activity of NMDA receptors at low firing frequencies, P2X receptors act as a dynamic low-frequency filter so that weak stimuli do not induce LTP.

Key words: $P 2 X$ receptors; long-term potentiation; NMDA receptor inactivation; $\alpha, \beta$-methyleneATP; PPADS; CA1 neurons
The activity-dependent phenomenon long-term potentiation (LTP) provides excitatory synapses with Hebbian properties and may serve as the basis of learning and memory. High-frequency stimulation (HFS) leads to LTP in hippocampal CA3-CA1 synapses because it allows postsynaptic NMDA receptors to create a powerful calcium signal in dendritic spines of depolarized pyramidal neurons. The level of intracellular calcium determines whether the efficacy of synaptic connections is enhanced or depressed (Artola and Singer, 1993; Debanne and Thompson, 1994; Malenka and Nicoll, 1999). Previously, NMDA receptors and voltage-gated $\mathrm{Ca}$ channels have been considered as the main source of calcium influx, particularly for CA1 hippocampal neurons. However, a role for a purinergic component of synaptic transmission has been demonstrated recently (Pankratov et al., 1999). ATP is released from nerve endings (Illes and Nurenberg, 1993; Zimmermann, 1994; Cunha et al., 1996), and ATP receptors show a widespread distribution in the brain (Balcar et al., 1995; Collo et al., 1996; Seguela et al., 1996). ATP acting at P2X receptors mediates synaptic transmission in the medial habenula (Edwards et al., 1992) and hippocampus (Pankratov et al., 1998). Nevertheless, the specific physiological role of ATP receptors in the CNS remains unclear. The effects of ATP are mediated by ionotropic $(\mathrm{P} 2 \mathrm{X})$ and metabotropic $(\mathrm{P} 2 \mathrm{Y})$ purinoreceptors. The former depolarizes neurons and has a considerable calcium permeability (Buell et al., 1996; Edwards et al., 1997; Virginio et al., 1998), whereas the latter controls calcium release from intracellular stores (Harden et al., 1995; Ralevic and Burnstock, 1998). The entry of calcium through purinoreceptor-operated channels

Received Jan. 25, 2002; revised June 18, 2002; accepted June 14, 2002.

This work was supported by a Howard Hughes Medical Institute grant and International Association for the Promotion of Cooperation with Scientists from the New Independent States of the Former Soviet Union Grant 99-01147. We are grateful to Drs. Urs Gerbert, Frances Edwards, and Alan North for early discussion and helpful comments.

Correspondence should be addressed to Prof. Oleg Krishtal, Department of Cellular Membranology, Bogomoletz Institute of Physiology, Bogomoletz Street 4, 01024 Kiev, Ukraine. E-mail: krishtal@serv.biph.kiev.ua.

Copyright (ㄷ) 2002 Society for Neuroscience 0270-6474/02/228363-07\$15.00/0 become larger with more negative membrane voltage in contrast to NMDA receptors for which calcium entry requires membrane depolarization. Thus, the purinergic component of synaptic transmission may increase intracellular calcium when the membrane potential is near its resting level. Correspondingly, the role of ionotropic purinergic component in the calcium signaling and synaptic plasticity may be quite different from the function of NMDA receptors. Here we show that inhibition of $\mathrm{P} 2 \mathrm{X}$ receptors facilitates the induction of LTP.

\section{MATERIALS AND METHODS}

Hippocampal slices. Experiments were performed on transverse 200- to $400-\mu \mathrm{m}$-thick hippocampal slices of Wistar rats (19- to -21-d-old animals). The brain was rapidly removed after decapitation and placed into ice-cold artificial CSF (ACSF) containing the following (in $\mathrm{mM}$ ): 130 $\mathrm{NaCl}, 3 \mathrm{KCl}, 1 \mathrm{MgCl}_{2}, 2 \mathrm{CaCl}_{2}, 1 \mathrm{NaH}_{2} \mathrm{PO}_{4}, 26 \mathrm{NaHCO}_{3}$, and 15 glucose (gassed with $95 \% \mathrm{O}_{2}-5 \% \mathrm{CO}_{2}$ to obtain a final $\mathrm{pH}$ of 7.4). After dissection, slices were placed in a holding chamber in which they were maintained at room temperature $\left(22-24^{\circ} \mathrm{C}\right)$ for $3-6 \mathrm{hr}$ until they were placed in the recording chamber, also at room temperature. During incubation and recording, slices were kept in ASCF of the following composition (in mM): $135 \mathrm{NaCl}, 2 \mathrm{KCl}, 2 \mathrm{CaCl}_{2}, 1.0 \mathrm{MgCl}_{2}, 1 \mathrm{NaH}_{2} \mathrm{PO}_{4}$, $26 \mathrm{NaHCO}_{3}$, and 15 glucose (gassed with $95 \% \mathrm{O}_{2}-5 \% \mathrm{CO}_{2}$ to obtain a final $\mathrm{pH}$ of 7.4).

Electrophysiological recordings. Using an RK-400 amplifier (Bio-Logic, Claix, France), the EPSCs were recorded in the conventional whole-cell configuration with the patch pipette $(2-5 \mathrm{M} \Omega$ ) filled with the following intracellular solution containing (in $\mathrm{mM}$ ): $80 \mathrm{~K}_{2} \mathrm{HPO}_{4}, 20 \mathrm{KCl}$, and 10 HEPES, pH 7.3 ("phosphate" solution). Two solutions were also used to test the role of intracellular calcium in the observed phenomena (in $\mathrm{mM}$ ): $110 \mathrm{CsCl}, 10 \mathrm{NaCl}, 10 \mathrm{HEPES}, \mathrm{pH}$ 7.3, $2 \mathrm{MgATP}$, and 0.1 EGTA ("CsCl 0.1 mm EGTA" solution); and $110 \mathrm{CsCl}, 10 \mathrm{NaCl}, 10 \mathrm{HEPES}, \mathrm{pH}$ 7.3, 2 MgATP, $1 \mathrm{CaCl}_{2}$, and 10 EGTA ("CsCl 10 mm EGTA" solution). The series and the input resistances were $7 \pm 3$ and $300 \pm 150 \mathrm{M} \Omega$, respectively, and varied for $<20 \%$ in the cells accepted for analysis. All of the recordings of excitatory synaptic currents were made in the presence of $100 \mu \mathrm{M}$ picrotoxin in the superfusing solution. The field EPSPs were recorded from the stratum radiatum of area CA1 using glass microelectrodes filled with ACSF (impedance, 1-2 M 2 ). The Schaffer collateral-commissural pathway was stimulated with a $50-\mu \mathrm{m}$-thick $\mathrm{Ni}-\mathrm{Cr}$ bipolar electrode positioned on the slice surface in the stratum 
radiatum. Stimulus intensity was adjusted to evoke EPSPs at $\sim 30-40 \%$ of the maximal response.

$\left[\mathrm{Ca}^{2+}\right]_{i}$ measurement. The hippocampal neurons were loaded with the calcium indicator fura- 2 by a 25 -min-long incubation of the hippocampal slices in the ACSF supplemented with fura-2 AM $(10 \mu \mathrm{M})$ and pluronic F-127 detergent $(0.02 \%)$ at $35^{\circ} \mathrm{C}$. For the period of dye loading, slices were kept under a controlled air environment $\left(\begin{array}{llll}5 \% & \mathrm{CO}_{2}-95 \% & \mathrm{O}_{2}\end{array}\right)$. Subsequently, the slices were incubated in ACSF for an additional $40 \mathrm{~min}$ to ensure fura-2 AM deetherification. For fura- 2 excitation, cells were illuminated at a wavelength of $390 \mathrm{~nm}$. The emitted light was collected at $530 \pm 10 \mathrm{~nm}$ by a photomultiplier controlled by a fura-2 Data Acquisition System (Luigs \& Neumann, Ratingen, Germany) and a TIDA interface (Heka Electronik, Lambrecht/Pfalz, Germany). To reduce the background fluorescence and select the region of interest, the UV illumination was attenuated by an adjustable diaphragm installed in the light path. Dye-loaded neurons were positioned in such a way that the fluorescent signal was collected from their somata. Relative changes in the $\left[\mathrm{Ca}^{2+}\right]_{i}$ were quantified as changes in $F / F_{0}$, where $F_{0}$ and $F$ are the fluorescence before and during neuronal activity (corrected for bleaching during recording). The bleaching was corrected by measuring the fluorescence in the neuron without stimulation. Tissue autofluorescence was subtracted after the measurement of fluorescence at a parallel location in the slice away from the dye-filled cell.

Acutely isolated pyramidal neurons. After dissection, hippocampal slices were placed in the ACSF supplemented with $0.8 \mathrm{mg} / \mathrm{ml}$ trypsin (type XI; Sigma, St. Louis, MO) and incubated at $32^{\circ} \mathrm{C}$ for $20 \mathrm{~min}$. After that, the slices were rinsed of the enzyme and maintained at room temperature $\left(22-24^{\circ} \mathrm{C}\right)$ for $4-6 \mathrm{hr}$. Single CA1 neurons were isolated by successive triturating through several pipettes with opening diameters from 0.5 to $0.1 \mathrm{~mm}$. After dissociation, neurons were placed in the extracellular solution containing the following (in $\mathrm{mM}$ ): $150 \mathrm{NaCl}, 5 \mathrm{KCl}, 2 \mathrm{CaCl}_{2}, 1$ $\mathrm{MgCl}_{2}$, and $10 \mathrm{HEPES}, \mathrm{pH}$ 7.3. The cells were suitable for recording within 2-3 hr. Only cells of characteristic pyramidal shape were used for the experiments. Whole-cell conventional patch-clamp recordings were performed by using the patch pipette (2-4 M $\Omega$ ) filled with the following intracellular solution (in mM): $120 \mathrm{CsCl}, 10 \mathrm{NaCl}, 10 \mathrm{HEPES}, 2 \mathrm{MgATP}$, and 0.1 EGTA, pH 7.3. The series and input resistance were $6 \pm 2$ and $800 \pm 200 \mathrm{M} \Omega$, respectively.

Drug application. A modified "square-pulse" concentration clamp method (Pankratov et al., 2001) was used for the rapid 200-msec-long application of agonist containing solutions with immediate washout. The tip of the recording pipette, attached to a neuron, was inserted into a glass tube $(1 \mathrm{~mm}$ inner diameter $)$ through a tiny opening $(0.6 \mathrm{~mm}$ inner diameter). The lower end of the tube was submerged into the external solution in the chamber. The upper end of the tube was connected via the $\mathrm{V}$-shaped plastic tube and computer-controlled valves to the sources of negative and positive pressures allowing the suction of drug-containing solution or backward washout with clear extracellular solution.

To examine the $\mathrm{Ca}^{2+}$ signals in pyramidal cells, ATP or $\alpha, \beta$ methyleneATP $(\alpha, \beta$-meATP) $(100 \mu \mathrm{M})$ were applied by pressure ejection $(5-10 \mathrm{kPa})$ from a pipette with a 200-300 $\mu \mathrm{m}$ internal diameter The pressure was switched by a solenoid valve controlled by computer. The pipette was positioned perpendicularly to the flow of the bath perfusing solution near the edge of stratum radiatum. The agonist was applied in the presence of $10 \mu \mathrm{M}$ (2,3-dioxo-6-nitro-1,2,3,4-tetrahydro-benzo[f]quinoxaline-7-)sulfonamide (NBQX) and $50 \mu \mathrm{M}$ 2-amino-5-phosphovaleric acid (D-APV) at $5 \mathrm{~min}$ intervals using $10 \mathrm{sec}$ pulses.

Data analysis. All data are expressed as mean \pm SD. The statistical analysis was performed using Origin 6.0 software (Microcal Software, Northampton, MA). The standard paired $t$ test was used for analysis of changes in the EPSP, and linear regression analysis was used to estimate the relationship between inactivation of NMDA receptors and P2X receptor-mediated current. The significance level of linear correlation was evaluated as probability, $p$, of null hypothesis, $H_{0}$, as defined by $F$ test.

Materials. The following compounds were purchased from Tocris Cookson (Bristol, UK): NBQX, D-APV, and pyridoxal phosphate-6azophenyl-2'-4'-disulphonic acid (PPADS). Fura-2 AM was delivered by Molecular Probes (Eugene, OR). All other chemicals were from Sigma.

\section{RESULTS}

Figure 1 shows that, with low-frequency stimulation of the Schaffer collaterals, a small fraction of the fast EPSC recorded in CA1 cells is mediated by ATP. After blocking glutamate receptors with NBQX and D-APV, the residual component can be inhibited a PPADS, $20 \mu \mathrm{M}$
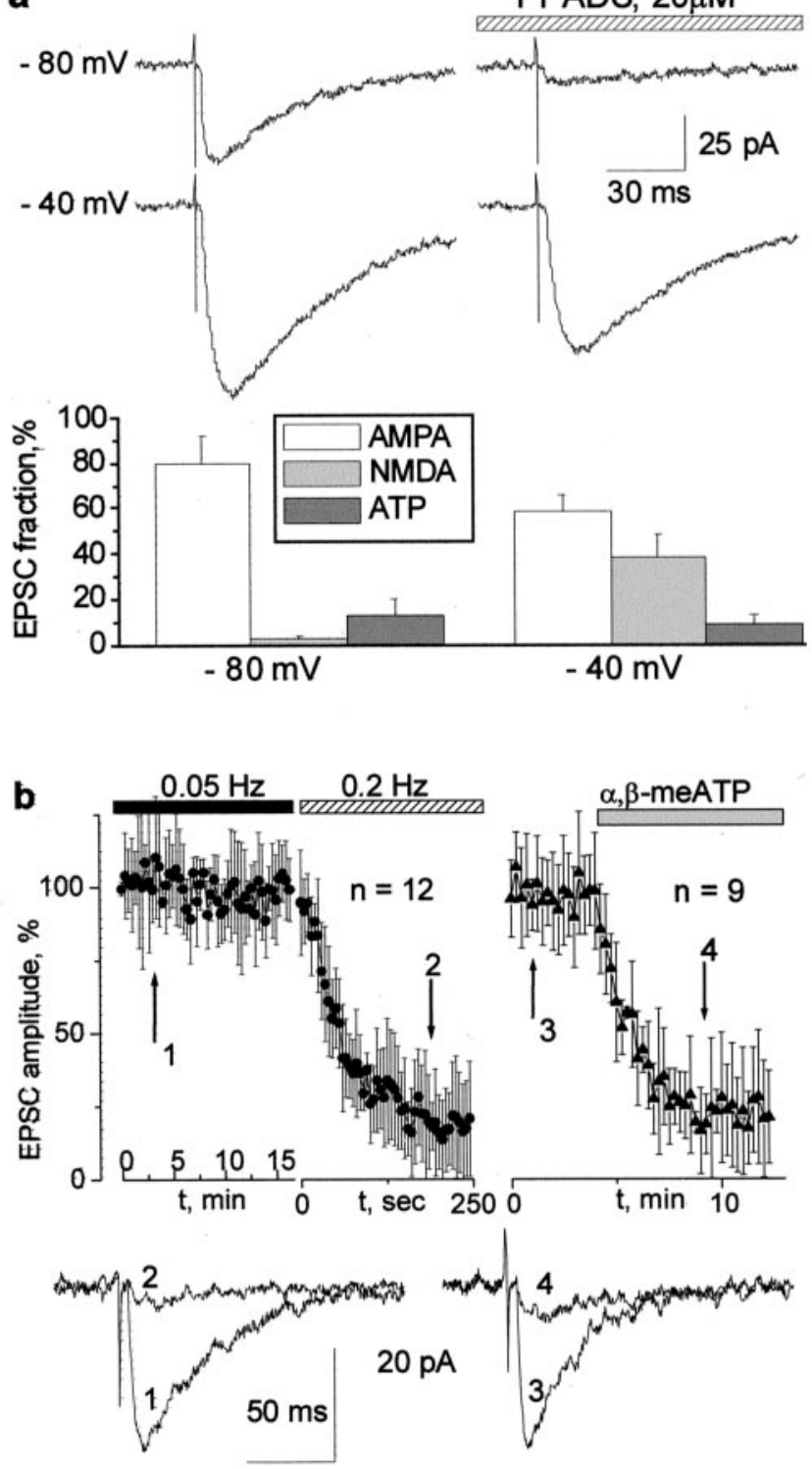

Figure 1. Purinergic synaptic input in hippocampal CA1 neurons. a, EPSCs elicited by stimulation of the Schaffer collaterals. The current was measured at two membrane voltages always in the presence of NBQX (10 $\mu \mathrm{M})$. Right column, Application of PPADS $(20 \mu \mathrm{M})$ on the background of NBQX. Each trace is the average of five consecutive responses. Note that, at a holding potential of $-80 \mathrm{mV}$, the EPSC consists almost entirely of P2X-mediated current. Bottom diagrams demonstrate the relative contribution of the AMPA, NMDA, and ATP receptor-mediated currents to the total EPSC. Each column represents the mean \pm SD for 15 cells. $b$, The desensitization of the ATP-mediated EPSC, measured in the presence of NBQX $(10 \mu \mathrm{M})$ and D-APV $(50 \mu \mathrm{M})$ at a holding voltage of -75 $\mathrm{mV}$. The top left graph demonstrates that the amplitude of the purinergic component of the EPSC in CA1 neurons is stable when the frequency of stimulation is $0.05 \mathrm{~Hz}$ but quickly fades when the frequency is increased to $0.2 \mathrm{~Hz}$. The top right graph demonstrates the disappearance of the purinergic component of the EPSC after bath application of $20 \mu \mathrm{M}$ $\alpha, \beta$-meATP, a nonhydrolyzable analog of ATP, with stimulation frequency of $0.05 \mathrm{~Hz}$. The representative current traces obtained at the times indicated by the arrows are demonstrated below the graphs.

by $20 \mu \mathrm{M}$ PPADS $(55 \pm 25 \% ; n=20)$. This ATP-mediated component comprised 5-20\% of the total synaptic current depending on the holding potential. With AMPA receptors only blocked, the residual postsynaptic current at $-80 \mathrm{mV}$ is almost 

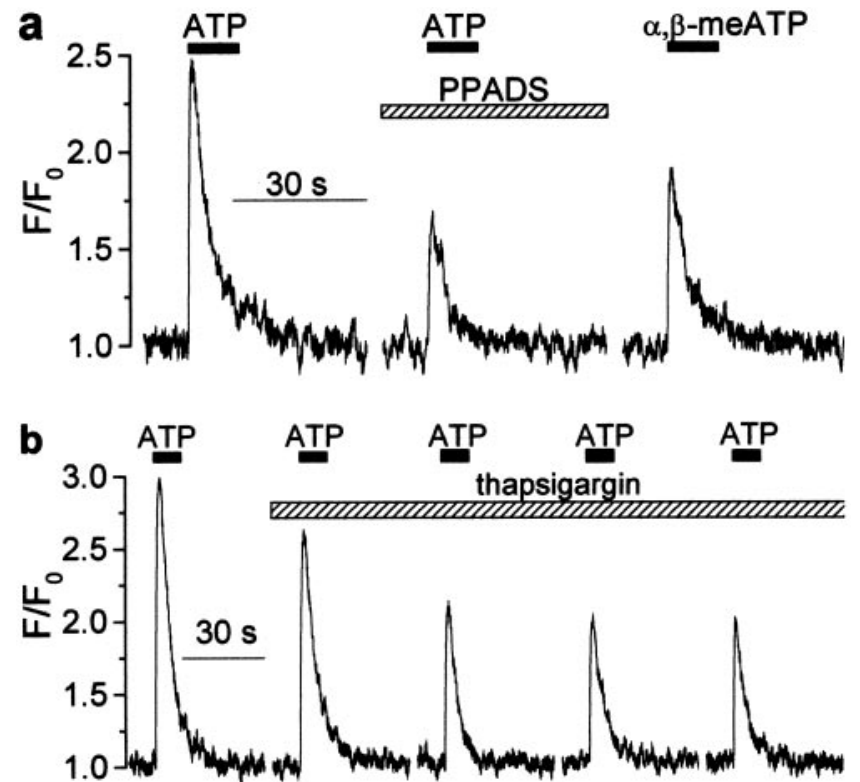

Figure 2. ATP-induced $\left[\mathrm{Ca}^{2+}\right]_{\mathrm{i}}$ transients in CA1 pyramidal neurons. $a$, Examples of $\left[\mathrm{Ca}^{2+}\right]_{i}$ transients induced in the pyramidal cells by fast application of ATP $(100 \mu \mathrm{M})$ and $\alpha, \beta$-methyleneATP $(100 \mu \mathrm{M})$ to the hippocampal slice in control and after bath application of $20 \mu \mathrm{M}$ PPADS. All traces were recorded in one and the same cell at 5 min intervals. Note the substantial amplitude of the response to $\alpha, \beta$-methyleneATP, which is only attributable to the calcium influx via ionotropic ATP-receptors. $b$, Examples of $\left[\mathrm{Ca}^{2+}\right]_{\mathrm{i}}$ transients induced by repetitive fast application of $\operatorname{ATP}(100 \mu \mathrm{M})$ in the presence of $1 \mu \mathrm{M}$ thapsigargin at 5 min time intervals. It is worth noting that the amplitudes of the third and the following transients, which are attributable to entry of the extracellular calcium via ionotropic ATP receptors, comprise $\sim 40 \%$ of the initial response, which represents the combined activity of $\mathrm{P} 2 \mathrm{X}$ and $\mathrm{P} 2 \mathrm{Y}$ purinoreceptors.

completely purinergic. At $-40 \mathrm{mV}$, the purinergic component is approximately one-fifth of the NMDA component. The purinergic component of the EPSC declined steeply when the stimulation frequency was increased to $0.2 \mathrm{~Hz}$ (Fig. 1b). A similar effect was seen by applying $20 \mu \mathrm{M} \alpha, \beta$-meATP, a nonhydrolyzable ATP receptor agonist (Buell et al., 1996), and we ascribe the disappearance of the purinergic component to the desensitization, which is commonly observed for P2X receptors. It should be noted that the effects of PPADS and $\alpha, \beta$-meATP, as well as the rate of desensitization of the ATP-mediated EPSCs, showed large cell to cell variations. A small fraction of the current (5-25\%) persists after application of PPADS and repeated episodes of high-frequency stimulation. This variability is most probably attributable to the differential expression of several P2X receptor subtypes, presumably $\mathrm{P} 2 \mathrm{X} 3, \mathrm{P} 2 \mathrm{X} 4$, and $\mathrm{P} 2 \mathrm{X} 6$, as well as their heteromers (Seguela et al., 1996; Ralevic and Burnstock, 1998). These receptors have different sensitivity to PPADS and $\alpha, \beta$-meATP, as well as different desensitization kinetics.

We measured $\left[\mathrm{Ca}^{2+}\right]_{\mathrm{i}}$ transients evoked in CA1 pyramidal cells by fast application of $100 \mu \mathrm{M}$ ATP to hippocampal slices (Fig. 2). Prominent signals were observed in 20 of 25 cells, and these were inhibited by $45 \pm 25 \%$ in the presence of PPADS $(20 \mu \mathrm{M} ; n=12)$. They were unaffected by $1 \mu \mathrm{M}$ tetrodotoxin and/or glutamate receptor blockers. $\alpha, \beta$-meATP at the concentration of $100 \mu \mathrm{M}$ also evoked calcium transients in 17 of 22 cells $(30-60 \%$ of the amplitude of those caused by ATP). $\alpha, \beta$-meATP does not activate P2Y receptors (Ralevic and Burnstock, 1998), so this experiment indicates that a substantial fraction of the rise in $\left[\mathrm{Ca}^{2+}\right]_{\mathrm{i}}$ results from influx through $\mathrm{P} 2 \mathrm{X}$ receptors. Blocking of refilling of the intracellular $\mathrm{Ca}^{2+}$ stores by thapsigargin (Lytton et al., 1991) decreased the calcium signal, indicating some contribution of the metabotropic signal and/or $\mathrm{Ca}^{2+}$-induced $\mathrm{Ca}^{2+}$ release (Fig. 2b). However, a substantial residual component remained (50 $\pm 15 \%$; $n=6$ ), demonstrating a substantial ionotropic $\mathrm{P} 2 \mathrm{X}$ receptormediated component.

An increase in postsynaptic calcium is widely believed to play a key role in synaptic plasticity (Bliss and Collingridge, 1993; Cummings et al., 1996; Malenka and Nicoll, 1999). The purinergic component of the EPSC might play an important role in longterm plasticity because the P2X-receptor mediated calcium entry would progressively increase with hyperpolarization. This is in contrast to the activation of NMDA receptors, in which current decreases with hyperpolarization beyond approximately $-40 \mathrm{mV}$. We elicited LTP at CA3-CA1 synapses according to established protocols and measured it as the slope of the field EPSP. In control conditions, high-frequency stimulation $(100 \mathrm{~Hz}, 1 \mathrm{sec})$ increased the slope by $125 \pm 45 \%$, and this increase persisted for up to $3 \mathrm{hr}$ (Fig. $3 a$ ). A train of $100 \mathrm{~Hz}$ for $0.2 \mathrm{sec}$ did not cause LTP, even when the train was repeated (Fig. 3b). However, in the presence of the P2X receptor blocker PPADS $(20 \mu \mathrm{M})$, even the short train evoked substantial LTP (Fig. $3 b$ ). The field EPSP slope increased by $69 \pm 34 \%$ at $1 \mathrm{hr}$, and this effect was highly significant ( $n=15 ; p<0.01$; Student's $t$ test).

The question arises whether the observed phenomenon is attributable to the presynaptic or postsynaptic action(s) of PPADS. This substance blocks both P2X and P2Y receptors (Buell et al., 1996). Metabotropic P2Y receptors are known to downregulate transmitter release by partial inhibition of Ca channels (Ralevic and Burnstock, 1998). Correspondingly, PPADS might enhance synaptic transmission via a presynaptic mechanism. In fact, we observed a small increase in the field EPSP in the presence of PPADS. The effect reached $6 \pm 4 \%$ for the mean amplitude and $8 \pm 6 \%$ for the coefficient of variation $(n=15)$. This minor effect does not seem to be capable of causing a profound facilitation of LTP, but we further addressed the problem by using $\alpha, \beta$-meATP as a desensitizing agonist, which is selective for P2X receptors (Ralevic and Burnstock, 1998). This substance did not increase the amplitude of EPSP but completely reproduced the effect of PPADS: LTP could be elicited by a 0.2 sec stimulus train in the presence of $20 \mu \mathrm{M} \alpha$, $\beta$-meATP (Fig. 3c), and the slope of the field EPSP was increased by $45 \pm 22 \%$ at 1 hr $(n=10 ; p<0.02$; Student's $t$ test $)$.

These results imply that the observed facilitation of LTP induction is predominantly related to the inhibition of the ionotropic P2X receptors. The experiments on isolated pyramidal neurons (see below) suggest that the affected $\mathrm{P} 2 \mathrm{X}$ receptors are postsynaptic.

The LTP at the CA1 synapse is NMDA receptor dependent (Bliss and Collingridge, 1993; Cummings et al., 1996). We checked whether the role of NMDA receptors in LTP induction remained crucial under conditions of inhibited $\mathrm{P} 2 \mathrm{X}$ receptors. Figure $4 a$ shows that, in the presence of D-APV, high-frequency stimulation induces only brief potentiation, followed by a modest long-term depression (LTD) of the field EPSP. This effect is reversible, and, after removing D-APV from the bath solution, LTP can be induced. The conversion of the effect of brief tetanic stimulation from LTP to LTD as a result of NMDA receptor inhibition has been reported previously (Cummings et al., 1996). PPADS did not alter this phenomenon, confirming that the intrinsic properties of LTP induction were similar. Under simultaneous action of D-APV and PPADS, 1 sec HFS induced depres- 

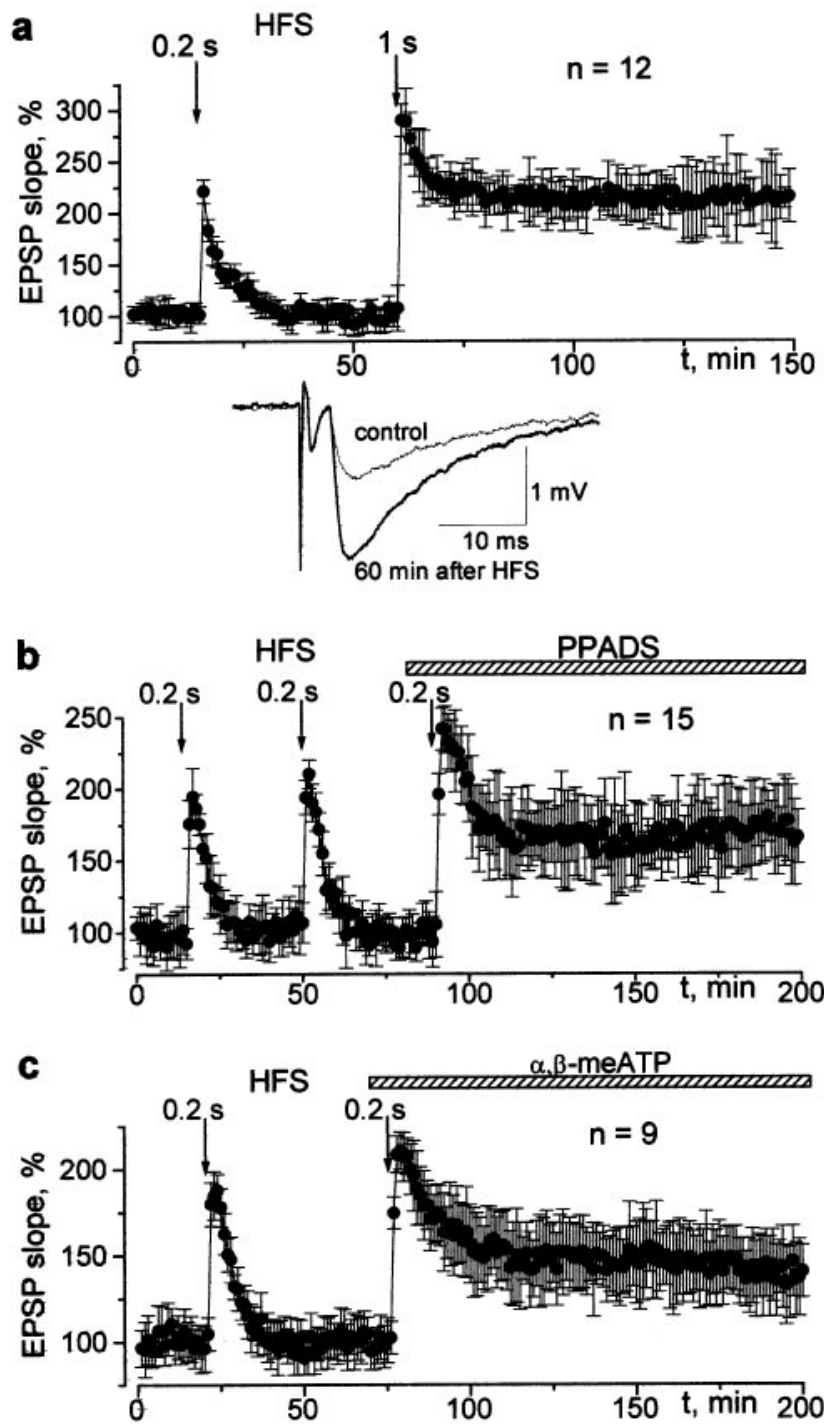

Figure 3. The changes in the CA1 field potentials induced by $100 \mathrm{~Hz}$ stimulation delivered to the Schaffer collateral in the control and after inhibition of the ATP receptors. $a$, The time course of the potentiation evoked by 0.2 and $1 \mathrm{sec}$ of $100 \mathrm{~Hz}$ stimulation trains in control conditions. Examples of field EPSPs recorded before and $60 \mathrm{~min}$ after the 1-sec-long HFS train are indicated in the inset. Each trace represents the average of 10 EPSPs. $b, c$, The time course and magnitude of the potentiation evoked by the $0.2 \mathrm{sec}$ HFS train in control and after bath application of $20 \mu \mathrm{M}$ PPADS and $\alpha, \beta$-methyleneATP, respectively. Baseline stimulation frequency is $0.08 \mathrm{~Hz}$.

sion instead of potentiation, but, during washout of D-APV, the $0.2 \mathrm{sec}$ HFS train induced LTP (Fig. 4b). These observations provide support for the hypothesis that the direction of the change in synaptic transmission depends on the level of the activity-dependent rise in $\left[\mathrm{Ca}^{2+}\right]_{\mathrm{i}}$ (Malenka and Nicoll, 1999; Luscher et al., 2000).

The above results suggest that ATP, coreleased with glutamate, causes an inhibition of LTP at low frequencies of background tonic stimulation. At higher frequencies of background stimulation, ATP loses its postsynaptic action attributable to desensitization of $\mathrm{P} 2 \mathrm{X}$ receptors. One mechanism by which $\mathrm{P} 2 \mathrm{X}$ receptors might affect the machinery of LTP could be through the $\mathrm{Ca}^{2+}$ dependent inactivation of NMDA-mediated responses (Rosenmund et al., 1995; Kyrozis et al., 1996). This hypothesis was tested,
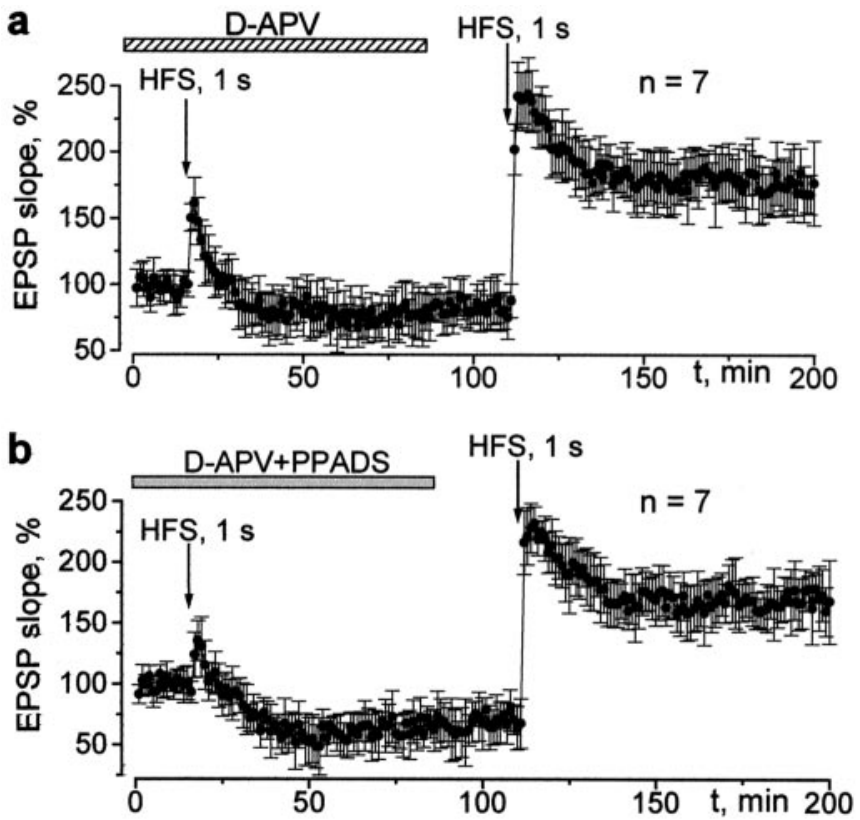

Figure 4. Inhibition of purinoreceptors does not affect the "NMDA paradigm." The changes in the field EPSP slope evoked by the $1 \mathrm{sec}$ HFS train after bath application of $25 \mu \mathrm{M}$ D-APV $(a)$ and simultaneous application of $25 \mu \mathrm{M}$ D-APV and $20 \mu \mathrm{M}$ PPADS $(b)$. The inhibition of NMDA receptors reversibly blocks the induction of LTP independently of the activity of $\mathrm{P} 2 \mathrm{X}$ receptors. Baseline stimulation frequency is $0.08 \mathrm{~Hz}$.

and the results are shown in Figure 5. The Schaffer collaterals were continuously stimulated in the presence of NBQX. The current measured at $-40 \mathrm{mV}$ represented the NMDA component of the EPSC, whereas an exclusively purinergic component was present at $-80 \mathrm{mV}$ (compare with Fig. 1a). The NMDA component was strongly inhibited after each episode of low-frequency stimulation at $-80 \mathrm{mV}$ (Fig. 5a). The gradual recovery of NMDA current during the stimulation at $-40 \mathrm{mV}$ is incomplete because of the calcium influx via NMDA receptor-operated channels. However, after a period without stimulation, the amplitude of NMDA receptor-mediated EPSC completely recovered (Fig. 5a). As already reported (Rosenmund et al., 1995; Kyrozis et al., 1996), NMDA receptors recover from inactivation when the calcium concentration falls back to resting levels. The inhibition of NMDA component was abolished by PPADS, suggesting that NMDA receptors were inhibited by the activity of $\mathrm{P} 2 \mathrm{X}$ receptors (Fig. $5 a$ ).

The inhibition of the NMDA component of the EPSC appears to be dependent on the calcium buffering capacity of the intracellular solution. Three compositions of intracellular solution were tested: one containing $\mathrm{K}_{2} \mathrm{HPO}_{4}$ (phosphate solution) and two CsCl-based solutions, with the solution with $10 \mathrm{~mm}$ EGTA providing very strong buffering of $\mathrm{Ca}^{2+}$ and the solution with 0.1 mM of EGTA allowing large variations in the intracellular $\mathrm{Ca}^{2+}$ concentration. These solutions may be ranked according to their potency as $\mathrm{Ca}^{2+}$ buffers from higher to lower: $10 \mathrm{~mm}$ EGTA solution, phosphate solution, and $0.1 \mathrm{~mm}$ EGTA solution. The inhibitory effect was evaluated as the difference in the steady level of amplitude of NMDA current before and after stimulation at $-80 \mathrm{mV}$. We did not observe the inhibition of NMDA currents in all of the cells perfused with $10 \mathrm{~mm}$ EGTA $(n=10)$. As to the cells perfused with $0.1 \mathrm{~mm}$ EGTA $(n=15)$, the inhibition of NMDA current was even larger than in the case of the phosphate solution (Fig. $5 b$ ). 
a

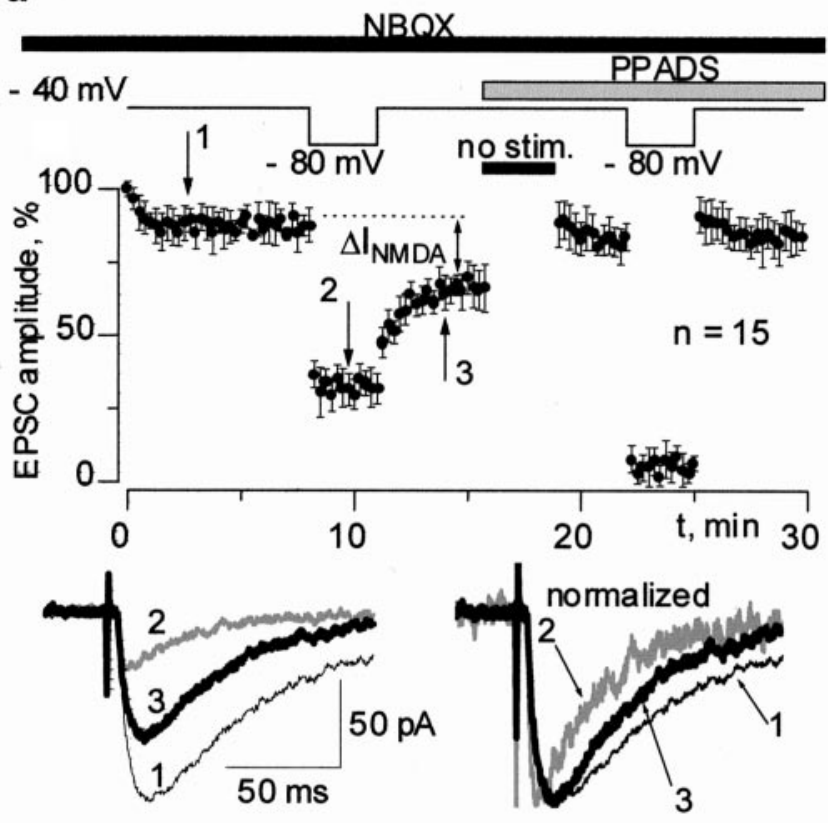

b

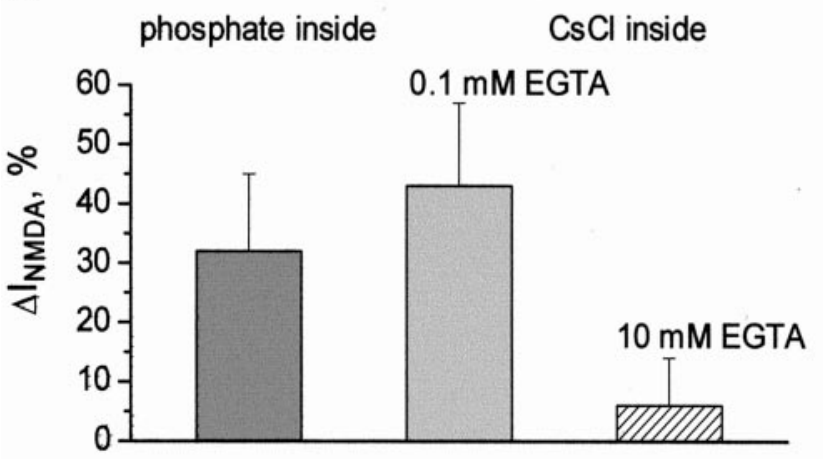

Figure 5. NMDA component of EPSC is inactivated by low-frequency stimulation at a strongly negative voltage. This effect is inhibited by PPADS and depends on the $\mathrm{Ca}^{2+}$-buffering capacity of the intracellular saline. $a$, EPSCs comprising NMDA and purinergic components were continuously recorded at two membrane potentials, first at $-40 \mathrm{mV}$ (practically pure NMDA component) and then at $-80 \mathrm{mV}$ (only the purinergic component is responsible for the measured inward current). Note a substantial inhibition of the NMDA component after return of the voltage to $-40 \mathrm{mV}$ (the EPSCs measured at the moments indicated by the numbers are demonstrated in the inset, and each trace is the average of 5 EPSCs). The kinetics of the EPSC recorded again at $-40 \mathrm{mV}$ become faster because of the decrease in the NMDA receptor-mediated fraction. Application of PPADS $(20 \mu \mathrm{M})$ to the same cell leads to the complete disappearance of this effect. $b$, A decrease in the NMDA receptormediated component of EPSC $\left(\Delta I_{\mathrm{NMDA}}\right)$ has been measured as shown in $a$ using different compositions of intracellular solution (see Materials and Methods). The buffering of intracellular calcium by 10 mM EGTA prevents the inactivation of NMDA receptors.

So, the stronger the buffering of intracellular $\mathrm{Ca}^{2+}$ was, the weaker was the inhibition of NMDA currents observed after a period of low-frequency stimulation at strongly negative membrane voltages. The inhibition of NMDA receptors could also be prevented by the purinergic antagonist PPADS. The above results suggest that $\mathrm{Ca}^{2+}$ influx mediated by purinoreceptors may bring a contribution in the inactivation of NMDA receptors. To obtain direct evidence of interaction between P2X and NMDA receptors, we performed experiments on dissociated pyramidal CA1 neurons. The inward currents evoked by application of ATP were observed in 19 of 24 cells tested. The amplitude of the response to $20 \mu \mathrm{M}$ ATP was in the range of $20-120 \mathrm{pA}$ at a holding potential of $-80 \mathrm{mV}$. The mean density of ATP-induced current was $4 \pm 2 \mathrm{pA} / \mathrm{pF}$. The decay of current had biexponential kinetics with time constants of $28 \pm 8$ and $850 \pm 150 \mathrm{msec}$, with the ratio of fast to slow components measuring $0.44 \pm 0.25$. These observations are consistent with the participation of different P2X receptor subtypes. All of the tested cells demonstrated a response to NMDA whose amplitude (200-300 pA) was stable during repetitive application of agonist at 2 min intervals. The amplitude of current evoked by the application of $30 \mu \mathrm{M}$ NMDA at $-40 \mathrm{mV}$ was typically two to three times higher than the amplitude of the response to $20 \mu \mathrm{M}$ ATP at $-80 \mathrm{mV}$.

When the response to NMDA was evoked in a few seconds after a short $(200 \mathrm{msec})$ application of ATP, the amplitude of NMDA current did not alter significantly. At the same time, when ATP was applied for a much longer time (10 sec) at a holding potential of $-80 \mathrm{mV}$, the amplitude of the NMDA response decreased considerably (Fig. $6 a$ ). The larger the response to ATP was, the higher was the decrease in the amplitude of NMDA receptor-mediated current. On the other hand, the inhibition of NMDA receptors was not observed in the cells that did not respond to ATP. The dependence of decrease in the amplitude of response to NMDA $\left(I_{\mathrm{NMDA}}\right)$ on the relative amplitude of $\mathrm{P} 2 \mathrm{X}$ receptor-mediated current $\left(I_{\mathrm{P} 2 \mathrm{X}} / I_{\mathrm{NMDA}}\right)$ is shown in Figure $6 b$.

The 10 -sec-long preapplication of $\alpha, \beta$-meATP $(20 \mu \mathrm{M})$ also inhibited the NMDA current (Fig. $6 b$ ), indicating that this effect is mediated predominantly by ionotropic P2X receptors. Moreover, the inhibitory effect of both $\mathrm{P} 2 \mathrm{X}$ receptor agonists correlated with the amplitude of the ATP-evoked current (Fig. 6b). The linear regression analysis gave the correlation coefficient $R>$ 0.7 with a significance level $p<0.01$, indicating toward the strong modulatory effect of ATP receptors.

For several cells, although they demonstrated a relatively small response to ATP, the inhibition of NMDA receptor-mediated currents by preapplication of ATP was very high, whereas such a deviation from the main correlation was not observed for $\alpha, \beta$ meATP. This fact implies that metabotropic P2Y receptors may also contribute to the rise in intracellular calcium and subsequent inhibition of NMDA receptors.

To prove the role of calcium in the inactivation of NMDA receptors, we reproduced the same protocol after substitution of extracellular calcium for barium. As shown in Figure $6 c$, application of ATP failed to induce NMDA receptor inactivation in the absence of calcium ions in the extracellular medium. Hence, the influx of calcium through $\mathrm{P} 2 \mathrm{X}$ receptor channels is crucial for ATP-induced inactivation of NMDA receptors.

\section{DISCUSSION}

Our data demonstrate that ATP receptors mediate a minor component of excitatory synaptic current and participate in the intracellular calcium signaling in CA1 pyramidal neurons. Although $\mathrm{P} 2 \mathrm{X}$ receptor-mediated synaptic input is small compared with the AMPA component, it may play an important role, providing a calcium influx at low membrane potentials when NMDA receptors are not active. Another important feature of purinergic synaptic current is its tendency to desensitization with increased stimulation frequency. Similar behavior was reported for purinergic EPSC in the medial habenula (Edwards et al., 1997), in which the number of failures increased at higher stimulation frequencies. The decline of purinergic EPSC may be related to the 


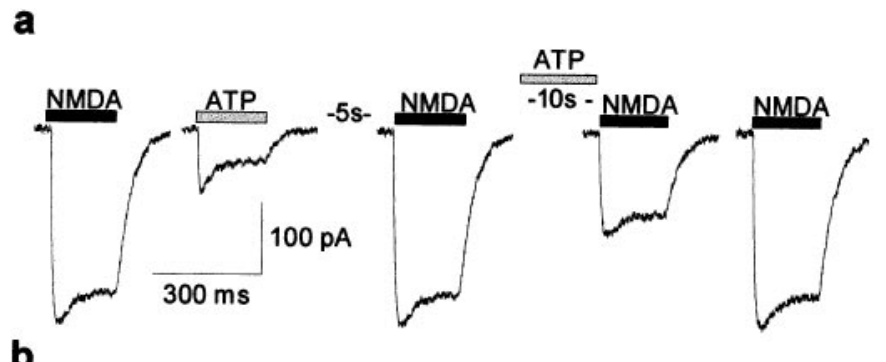

b

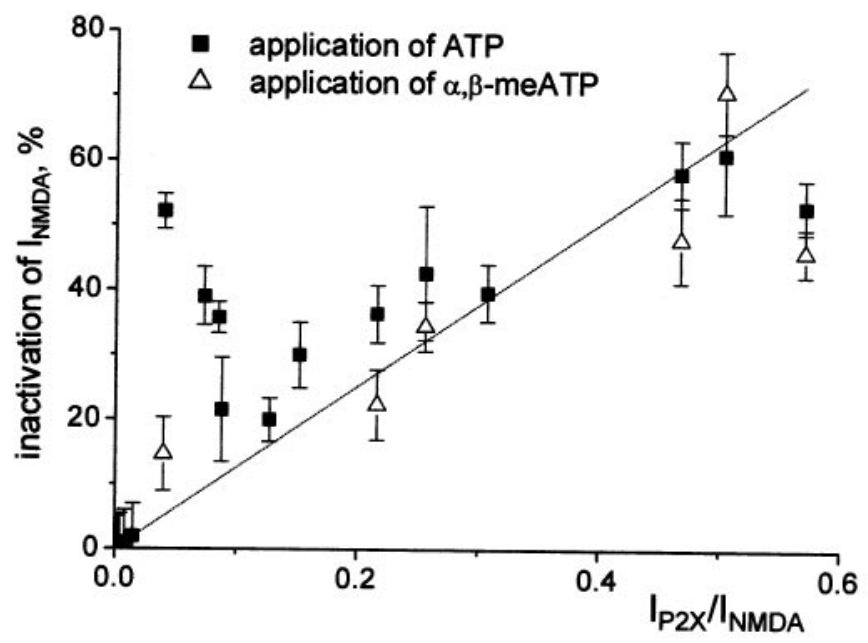

C

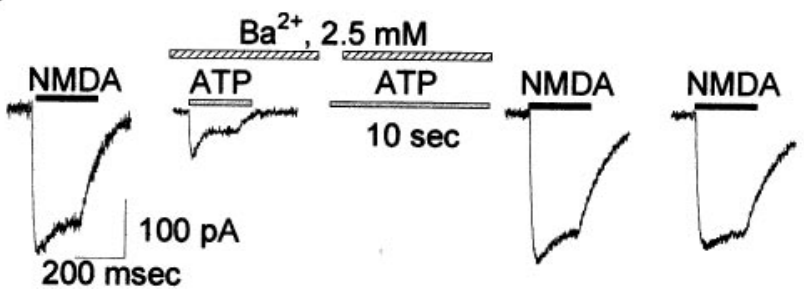

Figure 6. Interaction between $\mathrm{P} 2 \mathrm{X}$ and NMDA receptors in acutely isolated CA1 pyramidal neurons. $a$, examples of inward currents evoked by short (200 msec) applications of NMDA and ATP. The traces represent (from left to right) the control response to NMDA, the response to ATP, the control response to NMDA evoked $5 \mathrm{sec}$ after a $200 \mathrm{msec}$ application of ATP, the response to NMDA evoked after a $10 \mathrm{sec}$ preapplication of ATP, and the control response to NMDA. $b$, Inhibition of NMDA receptors correlates with the amplitude of response to ATP. The relative decrease in the amplitude of NMDA-evoked current $\left(I_{\text {NMDA }}\right)$ caused by 10-sec-long application of $\mathrm{P} 2 \mathrm{X}$ agonists (ATP, $20 \mu \mathrm{M}$, filled squares; $\alpha, \beta$-methyleneATP, $20 \mu \mathrm{M}$, open triangles) is plotted against the ratio of current mediated by $\mathrm{P} 2 \mathrm{X}$ receptors to the current mediated by NMDA receptors $\left(I_{\mathrm{P} 2 \mathrm{X}} / I_{\mathrm{NMDA}}\right)$. Each point represents a single cell tested. The inhibition of NMDA receptors is higher for the cells exhibiting larger $\mathrm{P} 2 \mathrm{X}$ receptors-mediated currents. The inhibition did not occur in the cells that did not exhibit the response to ATP. Several exclusions observed under ATP, but not $\alpha, \beta$-methyleneATP, can be tentatively attributed to the activity of $\mathrm{P} 2 \mathrm{Y}$ receptors in those particular three cells. The dotted line represents the result of linear regression analysis. A high (correlation coefficient, $R=0.72$ ) and significant $(p<0.01)$ correlation shows that ATP receptors can strongly influence the NMDA receptors. $c$, Substitution of calcium in the extracellular solution for barium eliminates the ATP-induced inactivation of NMDA receptors. The traces represent (from left to right) the control response to NMDA, the response to ATP after substitution of extracellular $\mathrm{Ca}^{2+}$ for $\mathrm{Ba}^{2+}$, the response to NMDA evoked after a $10 \mathrm{sec}$ preapplication of ATP in the $\mathrm{Ba}^{2+}$-containing medium, and the control response to NMDA. NMDA $(30 \mu \mathrm{M})$ was applied on the background of $10 \mu \mathrm{M}$ glycine at a holding potential of -40 $\mathrm{mV}$; ATP $(20 \mu \mathrm{M})$ was applied at $-80 \mathrm{mV}$. Intracellular solution contained $0.1 \mathrm{~mm}$ EGTA. desensitization of postsynaptic $\mathrm{P} 2 \mathrm{X}$ receptors, as well as downregulation of synaptic transmission by extracellular ATP via presynaptic P2Y purinoreceptors (Koizumi et al., 1997; Ralevic and Burnstock, 1998). Although presynaptic P2Y receptors may play a certain role in the synaptic plasticity, the effect of LTP facilitation observed in the present paper should be attributed mainly to P2X receptors, because a similar effect may result from the desensitization of $\mathrm{P} 2 \mathrm{X}$ receptors by their selective agonist $\alpha, \beta$-meATP.

The role of $\mathrm{P} 2 \mathrm{X}$ receptors is supported by data on the interaction between ATP- and NMDA-induced current. The observation of ATP-induced currents in the pyramidal neurons is important in itself as direct evidence of the presence of functional $\mathrm{P} 2 \mathrm{X}$ receptors. The percentage of cells that do not exhibit ATPinduced currents and calcium transients (20-25\%) is very close indeed to the percentage of failures in the observation of purinergic EPSCs (Pankratov et al., 1998). On the other hand, the variability of the P2X-mediated response recorded in the somata of isolated cells (Fig. 6b) is higher than the variability of synaptic current mediated by dendritic $\mathrm{P} 2 \mathrm{X}$ receptors. So one could suggest the different levels of $\mathrm{P} 2 \mathrm{X}$ receptor expression in the soma and dendrites of pyramidal neurons. Our results imply that, in at least $75-80 \%$ of pyramidal neurons, activity of $\mathrm{P} 2 \mathrm{X}$ receptors may cause $\mathrm{Ca}^{2+}$-dependent inactivation of NMDA receptors. It is not an unique example of interaction between $\mathrm{P} 2 \mathrm{X}$ and other ligand-gated receptor channels. The cross-inhibition between P2X and nicotinic acetylcholine receptors has also been widely reported (Nakazawa, 1994; Zhou and Galligan, 1998; Khakh et al., 2000). The mechanism of this effect seems to be different from inactivation of NMDA receptors. It has been demonstrated that interaction between purinergic and cholinergic receptors is $\mathrm{Ca}^{2+}$ independent (Zhou and Galligan, 1998) and presumably related to the spread of conformational changes from one receptor to its neighbor (Khakh et al., 2000).

The presented data indicate that the synaptic stimulation of $\mathrm{P} 2 \mathrm{X}$ receptors determines the level of activity of NMDA receptors by regulating dynamic equilibrium between periodical $\mathrm{Ca}^{2+}$ transients and mechanisms that bring $\mathrm{Ca}^{2+}$ concentration back to the resting levels. The level of intracellular $\mathrm{Ca}^{2+}$ is known to change the efficacy of synaptic connections in opposing ways by regulating phosphorylation and dephosphorylation. One of the most widely accepted views is that a moderate rise in the intracellular $\mathrm{Ca}^{2+}$ concentration should lead to the activation of phosphatases and cause LTD, whereas a larger rise in $\left[\mathrm{Ca}^{2+}\right]_{i}$ causes the activation of kinases, primarily of $\mathrm{Ca}^{2+} /$ calmodulindependent (CaM) kinase, subsequently leading to LTP. CaM kinase undergoes autophosphorylation and may remain active even after the return of $\left[\mathrm{Ca}^{2+}\right]_{i}$ to basal level. However, its opposing phosphatase has a 25-100 times higher affinity for calcium and can dephosphorylate the autophosphorylated kinase (Debanne and Thompson, 1994). Competition between these mechanisms provides the threshold for bi-directional long-lasting changes of synaptic connections. Two mutually nonexclusive hypotheses of the expression of synaptic plasticity are most widely accepted: (1) direct upregulation and downregulation of AMPA receptors (Malenka and Nicoll, 1999) and (2) morphological changes in the dendritic spines (Edwards, 1995; Luscher et al., 2000). Both hypotheses account for bi-directional changes in synaptic efficacy directed by the activity of phosphatases and kinases.

Our results on the participation of $\mathrm{P} 2 \mathrm{X}$ receptors in synaptic plasticity are in good agreement with the paradigm concerning the earlier phase of the LTP induction. Thus, in the vicinity of resting potential (that is, during the intervals between spikes or 
bursts), purinergic synaptic input may serve as the main source of intracellular calcium (Zimmermann, 1994; Cunha et al., 1996). This background calcium influx maintains the tonic activity of phosphatases and determines the efficiency of the subsequent episode of activity for the induction of LTP. In the course of such episodes, NMDA receptors available for activation in a given neuron have to create a sufficient calcium signal. The efficiency of NMDA receptors is determined, among other factors, by the level of calcium-dependent inactivation (Rosenmund et al., 1995). It appears that P2X receptors strongly influence the basal level of calcium-dependent inactivation of NMDA receptors and correspondingly determine the threshold for the induction of LTP.

In summary, our results indicate that ATP coreleased with glutamate allows calcium to enter the postsynaptic cell and thereby inhibits the effectiveness of NMDA receptors in the induction of LTP. P2X receptors bring their contribution to synaptic transmission mainly at low frequencies of stimulation and low membrane potential. In other words, they act as a dynamic low-frequency filter, preventing weak stimuli from inducing long-lasting changes in synaptic efficacy.

\section{REFERENCES}

Artola A, Singer W (1993) Long-term depression of excitatory synaptic transmission and its relationship to long-term potentiation. Trends Neurosci 18:41-48.

Balcar VJ, Li Y, Killinger S, Bennett MR (1995) Autoradiography of P2X ATP receptors in the rat brain. Br J Pharmacol 115:302-306.

Bliss TVP, Collingridge GL (1993) A synaptic model of memory: longterm potentiation in the hippocampus. Nature 361:31-39.

Buell G, Collo G, Rassendren F (1996) P2X receptors: an emerging channel family. Eur J Neurosci 8:2221-2228.

Collo G, North RA, Kawashima E, Merlo-Pich E, Neidhart S, Surprenant A, Buell G (1996) Cloning of P2X5 and P2X6 receptors and the distributions and properties of an extended family of ATP-gated ion channels. J Neurosci 16:2495-2507.

Cummings JA, Mulkey RM, Nicoll RA, Malenka RC (1996) $\mathrm{Ca}^{2+}$ signaling requirements for long-term depression in the hippocampus. Neuron 16:825-833.

Cunha RA, Vizi SE, Ribeiro AJ, Sebastiao AM (1996) Preferential release of ATP and its extracellular catabolism as a source of adenosine upon high- but not low-frequency stimulation of rat hippocampal slices. J Neurochem 67:2180-2187.

Debanne D, Thompson SM (1994) Calcium: a trigger for long-term depression and potentiation in the hippocampus. News Physiol Sci 9:257-260.

Edwards FA (1995) LTP - a structural model to explain the inconsistencies. Trends Neurosci 18:250-255.

Edwards FA, Gibb AJ, Colquhoun D (1992) ATP receptor-mediated synaptic current in the central nervous system. Nature 359:144-147.

Edwards FA, Robertson SJ, Gibb AJ (1997) Properties of ATP receptor- mediated synaptic transmission in the rat medial habenula. Neuropharmacology 36:1253-1268.

Harden TK, Boyer JL, Nicholas RA (1995) P2Y-purinergic receptors: subtype-associated signalling responses and structure. Annu Rev Pharmacol Toxicol 35:541-579.

Illes P, Nurenberg W (1993) Neuronal ATP receptors and their mechanism of action. Trends Pharmacol Sci 14:50-54.

Khakh BS, Zhou X, Sydes J, Galligan JJ, Lester HA (2000) Statedependent cross-inhibition between transmitter gated cation channels. Nature 406:405-410.

Koizumi S, Inoue K, Koch H (1997) Inhibition by ATP of calcium oscillations in rat cultured hippocampal neurones. Br J Pharmacol 122:51-58.

Kyrozis A, Albuquerque C, Gu J, MacDermott AB (1996) $\mathrm{Ca}^{2+}$. dependent inactivation of NMDA receptors: fast kinetics and high $\mathrm{Ca}^{2+}$ sensitivity in rat dorsal horn neurons. J Physiol (Lond) 495:449-463.

Luscher C, Nicoll RA, Malenka RC, Muller D (2000) Synaptic plasticity and dynamic modulation of the postsynaptic membrane. Nat Neurosci 3:545-550.

Lytton J, Waistline M, Hanley MR (1991) Thapsigargin inhibits the sarcoplasmic or endoplasmic reticulum Ca-ATPase family of calcium pumps. Biol Chem 266:17067-17071.

Malenka RC, Nicoll RA (1999) Long-term potentiation-a decade of progress? Science 285:1870-1874.

Mori M, Heuss C, Gahwiler BH, Gerber U (2001) Fast synaptic transmission mediated by $\mathrm{P} 2 \mathrm{X}$ receptors in CA3 pyramidal cells of rat hippocampal slice cultures. J Physiol (Lond) 535:115-123.

Nakazawa K (1994) ATP-activated current and its interaction with acetylcholine-activated current in rat sympathetic neurons. J Neurosci 14:740-750.

Pankratov Y, Castro E, Miras-Portugal MT, Krishtal O (1998) A purinergic component of the excitatory post-synaptic current mediated by $\mathrm{P} 2 \mathrm{X}$ receptors in the CA1 neurons of the rat hippocampus. Eur J Neurosci 10:3898-3902.

Pankratov Y, Lalo U, Castro E, Miras-Portugal MT, Krishtal O (1999) ATP receptor-mediated component of the excitatory synaptic transmission in the hippocampus. In: Progress in brain research, Vol 120 (Illes P, Zimmermann H, eds), pp 237-249. Amsterdam: Elsevier.

Pankratov Y, Lalo U, Dashkin A, Krishtal OA (2001) Heterogeneity of the functional expression of $\mathrm{P} 2 \mathrm{X} 3$ and $\mathrm{P} 2 \mathrm{X} 2 / 3$ receptors in the primary nociceptive neurons of rat. Neurochem Res 26:993-1000.

Ralevic V, Burnstock G (1998) Receptors for purines and pyrimidines. Pharmacol Rev 50:413-492.

Rosenmund C, Feltz A, Westbrook GL (1995) Calcium-dependent inactivation of synaptic NMDA receptors in hippocampal neurons. J Neurophysiol 73:427-430.

Seguela P, Haghighi A, Soghomonian J, Cooper E (1996) A novel neuronal P2X ATP receptor ion channel with wide distribution in the brain. J Neurosci 16:448-455.

Virginio C, North A, Surprenant A (1998) Calcium permeability and block at homomeric and heteromeric $\mathrm{P} 2 \mathrm{X}_{2}$ and $\mathrm{P} 2 \mathrm{X}_{3}$ receptors, and $\mathrm{P} 2 \mathrm{X}$ receptors in rat nodose neurons. J Physiol (Lond) 510:27-35.

Zhou X, Galligan JJ (1998) Non-additive interaction between nicotinic cholinergic and P2X purine receptors in guinea-pig enteric neurons in culture. J Physiol (Lond) 513 3:685-697.

Zimmermann H (1994) Signalling via ATP in the nervous system. Trends Neurosci 17:420-426. 